\title{
Pengembangan Panduan Sosiodrama untuk Meningkatkan Kecerdasan Interpersonal Siswa SMP Negeri 1 Ngoro
}

\author{
Shafira Yanwa Salsabila*, Lutfi Fauzan, IM. Hambali \\ Universitas Negeri Malang, Jl. Semarang No. 5 Malang, Jawa Timur, Indonesia \\ *Penulis korespondensi, Surel: shafirayanwa37@gmail.com
}

Paper received: 2-1-2021; revised: 23-1-2021; accepted: 30-1-2021

\begin{abstract}
The aim of this research is to produce a sociodrama guidebook to improve interpersonal intelligence of SMP Negeri 1 Ngoro students. The method used is research and development which adapts Borg and Gall's development model. This development model consists of five steps to the product revision stage after an assessment is carried out by 1 material expert test, 1 media expert test, and 1 prospective user test (counselor). The data collection technique was carried out by interviewing with 1 counselor and distributing an inventory of interpersonal intelligence to 32 students. The data analysis used was quantitative and qualitative data analysis. The results of the evaluation of the material expert test got an average total of 3.7, the media expert test got an average total of 3.9 and the prospective user test (counselor) got an average score of 3.9. Based on the expert's judgment that the manual is suitable for use.
\end{abstract}

Keywords: guidebook; sociodrama; interpersonal intelligence

\begin{abstract}
Abstrak
Penelitian ini bertujuan untuk menghasilkan panduan sosiodrama untuk meningkatkan kecerdasan interpersonal siswa SMP Negeri 1 Ngoro. Metode yang digunakan adalah penelitian dan pengembangan yang mengadaptasi model pengembangan Borg dan Gall. Model pengembangan ini terdiri dari lima langkah sampai tahap revisi produk setelah dilakukan penilaian oleh 1 uji ahli materi, 1 uji ahli media, dan 1 uji calon pengguna (konselor). Teknik pengumpulan data dilakukan dengan wawancara bersama 1 konselor dan menyebar inventori kecerdasan interpersonal kepada 32 siswa. Analisis data yang digunakan adalah analisis data kuantitatif dan kualitatif. Hasil penilaian uji ahli materi mendapat total rata-rata sebesar 3,7 uji ahli media mendapat total rata-rata sebesar 3,9 dan uji calon pengguna (konselor) mendapat skor rata-rata sebesar 3,9. Berdasarkan penilaian dari ahli bahwa buku panduan tersebut layak digunakan.
\end{abstract}

Kata kunci: buku panduan; sosiodrama; kecerdasan interpersonal

\section{Pendahuluan}

Havighurst (Hurlock, 1995: 10) mengemukakan bahwa dalam perkembangannya hubungan sosial remaja memiliki tugas perkembangan yang menitikberatkan kepada hubungan sosial yang diantaranya: mencapai hubungan baru yang lebih matang dengan teman sebaya baik pria maupun wanita, mengharapkan dan mencapai perilaku sosial yang bertanggung jawab, serta memperoleh perangkat nilai dan sistem etis sebagai pegangan untuk berperilaku mengembangkan ideologi.

Menurut Gardner (1983) kecerdasan interpersonal adalah (1) kemampuan atas pemahaman perasaan orang lain (empati), (2) kemampuan seseorang untuk berhubungan dengan orang lain, (3) pemahaman akan perilaku, (4) pemahaman akan komunikasi, (5) pemahaman hubungan antara seseorang dengan situasi di sekitarnya, (5) kemampuan untuk mengekspresikan perasaannya lewat body language, dan (6) interpretasi mood seseorang lewat raut wajahnya. Individu yang memiliki kecerdasan interpersonal yaitu mampu bekerja 
sama dalam suatu organisasi serta dapat berkomunikasi dengan baik secara lisan maupun non lisan dengan orang lain. Pada lingkup sekolah, kecerdasan interpersonal penting bagi perkembangan siswa sebagai bekal dalam melanjutkan kehidupan. Kecerdasan interpersonal yang baik dapat mendukung siswa dalam mencapai keberhasilan.

Berdasarkan hasil wawancara peneliti dengan konselor SMP Negeri 1 Ngoro, permasalahan yang terjadi di lapangan yaitu kecerdasan interpersonal siswa dengan siswa lainnya masih rendah. Hasil dari need assessment menunjukkan nilai tertinggi 113 dan nilai terendah 81, dengan jumlah 32 siswa. Terdapat 20 siswa yang mempunyai nilai tertinggi, sedangkan 12 siswa yang mempunyai nilai terendah. Hasil tersebut relevan dengan hasil wawancara dengan konselor yang mengatakan bahwa siswa kelas 7 cenderung menyendiri karena masih kesulitan dalam menjalin pertemanan dengan teman sebayanya.

Rini Kartiko Sari \& Imam Setyawan (2018) tentang hubungan kecerdasan interpersonal dengan intensi perundungan pada siswa sekolah menengah pertama di Semarang, menunjukkan bahwa siswa dengan kecerdasan interpersonal yang tinggi akan memiliki kemampuan empati, sikap prososial, kesadaran diri, pemahaman situasi sosial dan etika sosial, pemecahan masalah, kemampuan berkomunikasi dan kemampuan mendengarkan.

Farah Arju (2017) tentang hubungan kecerdasan interpersonal dengan konsep diri, mengatakan bahwa kemampuan siswa dalam membentuk konsep dirinya tidak hanya berasal dari dirinya sendiri. Akan tetapi, interpersonal positif yang ditandai dengan adanya kemampuan dalam berinteraksi yaitu menciptakan, membangun, dan mempertahankan relasi juga mampu membentuk konsep diri sehingga siswa mampu memberikan gambaran dirinya.

Remaja yang memiliki kecerdasan interpersonal tinggi yaitu mampu bekerja sama dalam suatu organisasi serta dapat berkomunikasi dengan baik secara lisan maupun non-lisan dengan orang lain. Remaja yang sulit berkomunikasi dan bersosialisasi dengan teman sebaya dan masyarakatnya belum mempunyai rasa empati terhadap orang lain. Dalam kehidupan sehari-hari remaja masih cenderung memiliki sifat egois lebih mementingkan dirinya sendiri, kurang mempunyai sikap saling tolong menolong terhadap teman dan kurang peka terhadap perasaan orang lain. Mereka ada kalanya berada di lingkungan bersikap acuh tak acuh dan susah diajak bekerja sama, hal ini menunjukkan bahwa kecerdasan interpersonal remaja masih rendah. Apabila remaja memiliki komunikasi interpersonal yang remaja remaja akan merasa terasingkan dan terkucilkan dalam lingkungannya sehingga semakin kesulitan dalam berinteraksi dengan orang lain.

Terdapat beberapa cara atau teknik yang dapat digunakan untuk meningkatkan kecerdasan interpersonal siswa, yaitu dengan menggunakan teknik sosiodrama pada layanan bimbingan kelompok. Moreno (1987: 18) menyatakan sosiodrama adalah suatu teknik dalam kelompok dimana individu dapat berlatih agar dapat berfungsi lebih efektif dalam realitas kehidupan. Permainan peranan dalam hubungan antarpribadi berusaha untuk menciptakan suasana spontanitas dan kreativitas dimana tekanan-tekanan yang menghambat dihilangkan, dan individu mendapat kesempatan untuk belajar dalam suasana yang bebas tanpa hambatan.

Berdasarkan pemaparan masalah diatas, seharusnya siswa pada jenjang Sekolah Menengah Pertama sudah mampu dalam meningkatkan kecerdasan interpersonal. Kecerdasan interpersonal dapat ditingkatkan dengan layanan bimbingan dan konseling dengan teknik 
sosiodrama. Akan tetapi, konselor belum banyak yang menerapkan karena belum ada panduan yang memudahkan untuk melaksanakannya.

\section{Metode}

Metode yang digunakan dalam penelitian ini adalah penelitian dan pengembangan yang mengadaptasi model pengembangan Borg dan Gall. Model pengembangan ini terdiri dari 10 langkah, akan tetapi peneliti menggunakan 5 tahap yaitu (1) Tahap I Tahap penelitian dan pengumpulan data (2) Tahap II Perencanaan pengembangan (3) Tahap III Pengembangan Produk awal (4) Tahap IV Uji Coba Ahli, (5) Tahap V Revisi Produk Akhir Berupa Buku Panduan. Subjek pada penelitian dan pengembangan ini dilakukan melalui dua tahapan yaitu uji ahli dan uji calon pengguna. Uji ahli materi dari jurusan Bimbingan dan Konseling, uji ahli media dari jurusan Teknologi Pendidikan. Tahapan yang selanjutnya yaitu uji coba calon pengguna. Uji coba calon pengguna melibatkan konselor SMP Negeri 1 Ngoro.

Instrumen yang digunakan dalam penelitian dan pengembangan ini adalah instrumen uji ahli dan uji calon pengguna (konselor) dibuat untuk memberikan penilaian terhadap buku panduan yang telah dikembangkan. Instrumen uji ahli dan uji calon pengguna berupa skala penilaian terkait dengan aspek ketepatan, kebergunaan, kemudahan, dan kemenarikan.

Analisis data yang digunakan adalah analisis data kuantitatif dan kualitatif. Analisis data digunakan dalam menganalisis produk pengembangan berupa buku panduan. Analisis data kuantitatif menggunakan rumus rentangan atau rata-rata (mean). Hasil rata-rata yang tinggi menunjukkan bahwa produk tersebut layak. Sedangkan data kualitatif diperoleh dari penilaian ahli dan calon pengguna berupa kritik, saran dan komentar perbaikan.

\section{Hasil dan Pembahasan}

\subsection{Hasil}

Penelitian dan pengembangan menghasilkan produk berupa buku panduan sosiodrama untuk meningkatkan kecerdasan interpersonal siswa. Produk yang dihasilkan untuk konselor sebagai acuan dalam memberikan layanan kepada siswa. Dalam buku panduan ini terdapat empat bab. Bab yang pertama yaitu terdiri dari latar belakang, petunjuk umum dan khusus, peran konselor, peran siswa, tujuan buku, dan sasaran buku panduan. Bab yang kedua yaitu kajian teori yang terdiri dari pengertian sosiodrama, tujuan pelaksanaan, prosedur pelaksanaan, cara mengulang permainan, pengertian kecerdasan interpersonal, dimensi kecerdasan interpersonal, dan faktor yang memengaruhi kecerdasan interpersonal. Bab ketiga yaitu terdiri dari prosedur pelaksanaan sosiodrama untuk meningkatkan kecerdasan interpersonal. Bagian yang keempat terdiri dari evaluasi proses dan evaluasi hasil. Serta terdapat daftar rujukan dan lampiran. Berikut merupakan hasil penilaian dari ahli materi, ahli media, dan calon pengguna (konselor). 
Tabel 1. Hasil Penilaian Panduan oleh Ahli Materi, Ahli Media

\begin{tabular}{cccc}
\hline \multirow{2}{*}{ No } & Aspek & \multicolumn{2}{c}{ Ahli } \\
\cline { 3 - 4 } & & Penilaian Ahli Materi & Penilaian Ahli Media \\
\hline 1 & Aspek Kegunaan & Skor rata-rata 4 & Skor rata-rata 4 \\
2 & Aspek Ketepatan & Skor rata-rata 3,5 & Skor rata-rata 4 \\
3 & Aspek Kemudahan & Skor rata-rata 3,6 & Skor rata-rata 4 \\
4 & Aspek Kemenarikan & Skor rata-rata 3,4 & Kor rata-rata 3,8 \\
5 & Rata-rata & 3,6 & 3,9 \\
\hline
\end{tabular}

Berdasarkan saran yang diberikan uji ahli materi yaitu sebaiknya alokasi waktu dalam RPLBK ditentukan sesuai jenjang Sekolah Menengah Pertama yaitu 40 menit, perumusan tujuan umum dan khusus dalam RPLBK sebaiknya mengandung unsur kognitif, afektif dan psikomotorik, diperbaiki instrumen evaluasi hasil, item yang dikembangkan mengarah pada pencapaian tujuan layanan, dan di buku panduan belum ada penjelasan nomor item yang termasuk item favorable atau unfavorable. Berdasarkan ahli media yaitu secara umum sudah cukup baik, dan layak untuk diimplementasikan.

Tabel 2. Hasil Penilaian Panduan oleh Calon Pengguna

\begin{tabular}{lcc}
\hline No & Aspek & Penilaian Calon Pengguna (Konselor) \\
\hline 1 & Aspek Kegunaan & Skor rata-rata 3,8 \\
2 & Aspek Ketepatan & Skor rata-rata 3,8 \\
3 & Aspek Kemudahan & Skor rata-rata 4 \\
4 & Aspek Kemenarikan & Skor rata-rata 4 \\
5 & Rata-rata & 3,9 \\
\hline
\end{tabular}

Berdasarkan komentar yang diberikan oleh calon pengguna (konselor) yaitu buku panduan ini sangat baik untuk memudahkan konselor dalam memberikan layanan bimbingan di kelas dan memperkaya wawasan konselor. Bahasa yang digunakan dalam buku panduan ini mudah dipahami. Penilaian uji coba produk yang dikembangkan berupa panduan sosiodrama untuk meningkatkan kecerdasan interpersonal dapat dikatakan layak dan dapat digunakan oleh konselor.

\subsection{Pembahasan}

Penelitian dan pengembangan ini menghasilkan produk berupa buku panduan sosiodrama untuk meningkatkan kecerdasan interpersonal. Model penelitian pengembangan ini mengadaptasi model pengembangan Borg and Gall. Secara teoritis, model pengembangan Borg and Gall (1983) terdiri dari sepuluh tahap. Pada penelitian ini disesuaikan dengan kebutuhan penelitian sehingga diselesaikan sampai 5 tahap yaitu (1) Tahap I Tahap penelitian dan pengumpulan data (2) Tahap II Perencanaan pengembangan (3) Tahap III Pengembangan Produk awal (4) Tahap IV Uji Coba Ahli, (5) Tahap V Revisi Produk Akhir Berupa Buku Panduan.

Terdapat lima judul berbeda pada setiap pertemuan, diantaranya meliputi belajar berempati, membantu orang lain yang membutuhkan, menyelesaikan masalah dengan segera, belajar mengontrol emosi dan menghargai pendapat orang lain. Judul skenario yang di pada skenario Terdapat tujuh pertemuan dengan durasi waktu pertemuan 1x40 menit yang setiap 
pertemuan dilengkapi dengan RPLBK terlampir. Hal ini didukung oleh Cheng, dkk. (2013) bahwa durasi waktu merupakan hal yang akan menentukan kebutuhan target audience.

Produk buku panduan yang dikembangkan sudah tervalidasi oleh satu orang ahli materi dan satu orang ahli media dan satu orang calon pengguna produk (konselor). Pelaksanaan uji coba ahli didasarkan pada pernyataan Sukmadinata (2016) bahwa uji coba dari para ahli sangat penting untuk mengetahui kelayakan dasar-dasar konsep atau teori yang digunakan untuk melihat kelayakan secara praktis. Hasil penilaian uji ahli materi dari bimbingan dan konseling yang didasarkan pada 4 aspek keberterimaan: ketepatan, kegunaan, kemudahan, dan kemenarikan. Penilaian menggunakan perhitungan model rata-rata menunjukkan skor 3,6 yang artinya sangat layak digunakan. Pada aspek kegunaan mendapatkan rata-rata skor 4 yang artinya sangat berguna dalam membantu konselor memberikan layanan serta meningkatkan keefektifan layanan bimbingan dan konseling.

Pada aspek ketepatan memperoleh rata-rata 3,5 yang artinya sangat tepat mulai dari ketepatan judul, sasaran, petunjuk penggunaan, prosedur pelaksanaan, model evaluasi, dan penggunaan bahasa. Produk ini memiliki prosedur yang didalamnya tersusun langkah-langkah sesuai dengan pendapat Romlah (2013: 104) mengemukakan bahwa langkah-langkah pelaksanaan sosiodrama secara umum terdiri dari (1) persiapan, (2) membuat skenario sosiodrama, (3) menentukan kelompok pemain, (4) menentukan kelompok penonton, (5) pelaksanaan sosiodrama, (6) evaluasi dan diskusi serta (7) ulangan permainan jika diperlukan.

Aspek kemenarikan mendapatkan rata-rata skor 3,4 yang artinya menarik mulai dari isi materi, teknik layanan layanan yang digunakan serta keseluruhan buku panduan. Aspek kemudahan mendapat total skor 3,6 yang artinya sangat mudah. mulai dari kemudahan penggunaan buku panduan bagi konselor mendapatkan nilai 4, kemudahan bahasa dan sistematika buku panduan. Sesuai dengan pendapat yang dikemukakan Anggraini \& Wiyono (2020) bahwa buku panduan merupakan salah satu media atau bahan belajar yang dirancang dan disusun khusus secara sistematis, menarik, dan disertai dengan ilustrasi.

Hasil dari penilaian ahli media dengan menggunakan perhitungan model rata-rata menunjukkan total skor 3,8 yang artinya sangat layak untuk digunakan. Pada aspek ketepatan memperoleh rata-rata skor 4 yang artinya produk tersebut sangat tepat dalam segi ukuran font, desain sampul, perpaduan warna, penggunaan bahasa dan pemilihan tema gambar. Sesuai dengan pendapat Hurlock (2006) masa remaja awal berlangsung dari 13 tahun sampai dengan 17 tahun, sehingga desain sampul sudah sesuai dengan perkembangan Siswa Menengah Pertama. Aspek kegunaan yang dinilai uji ahli media mendapat rata-rata skor 4 yang artinya sangat berguna karena produk tersebut membantu konselor dalam memberikan layanan bimbingan dan konseling. Pada aspek kemudahan mendapatkan rata-rata skor 4 yang artinya sangat mudah dalam segi kemudahan dalan petunjuk penggunaan konselor, pemilihan font, dan pemilihan bahasa. Aspek kemenarikan mendapatkan rata-rata skor 3,8 yang artinya produk pengembangan sangat menarik mulai dari warna, ukuran kertas, layout, dan kemenarikan gambar pada isi media. Sesuai dengan pendapat Tiwasing, Sahachaisaeree, \& Hapeshi (2014) desain layout menarik yang mampu mendapat perhatian siswa, dan penggunaan gambar yang menarik mampu membuat orang tertarik. Baloglu \& McCleary, (1999).

Penilaian yang terakhir yakni calon pengguna produk (konselor) yang mendapatkan rata-rata skor 4 artinya produk pengembangan sangat layak. Aspek ketepatan memperoleh 
skor 3,8. Produk dinilai sangat tepat dari segi isi materi, ketepatan sasaran penggunaan, petunjuk penggunaan, ketepatan prosedur pelaksanaan layanan, model evaluasi layanan, ketepatan dalam penggunaan bahasa dalam buku panduan. Aspek kemudahan mendapat nilai rata skor 4 yang artinya sangat mudah dari segi timeline rancangan pelaksanaan, petunjuk penggunaan, bahasa yang digunakan, dan kemudahan sistematika layanan bimbingan dengan teknik sosiodrama. Hal ini sejalan dengan pendapat Wagiran (dalam Utomo 2008) bahwa buku yang dirancang dengan baik dan benar akan dapat berfungsi sebagai alat pembelajaran yang efektif.

Aspek kegunaan mendapat nilai rata-rata skor 3,8 yang artinya produk tersebut sangat berguna mulai dari kegunaan petunjuk umum dan khusus, uraian prosedur layanan, uraian teknik sosiodrama, dan kegunaan seluruh isi buku panduan, hal ini sejalan dengan pendapat Santoso (2013) salah satu tugas konselor yaitu secara maksimal dapat memfasilitasi konseli mengaktualisasikan potensi yang dimiliki secara optimal. Pada aspek kemenarikan mendapat nilai rata-rata skor 4 yang artinya sangat menarik dari segi kemenarikan desain buku, pemilihan topik materi, teknik layanan, dan kemenarikan keseluruhan buku panduan. Maka dari itu, produk pengembangan buku panduan disusun secara rinci, bahasa mudah dipahami, huruf dan tampilan yang menarik agar buku panduan yang disusun mudah digunakan konselor dalam memberikan layanan.

Interpretasi dari hasil keseluruhan penilaian produk penelitian dan pengembangan melihat dari rumus yang dicantumkan oleh Rasyid (2019). Sehingga interpretasi dari penilaian tersebut menunjukkan bahwa buku panduan sosiodrama untuk meningkatkan kecerdasan interpersonal siswa sangat berterima sebagai panduan yang digunakan baik secara teoritis maupun praktis dari aspek kegunaan, ketepatan, kemudahan dan kemenarikan.

Buku panduan sosiodrama untuk meningkatkan kecerdasan interpersonal yang dikembangkan oleh peneliti dinilai sangat layak dari segi isi materi, format buku panduan dan format media yang telah tervalidasi oleh uji ahli materi, uji ahli media dan calon pengguna produk . Dari segi isi materi berisi tentang pengertian kecerdasan interpersonal, unsur-unsur kecerdasan interpersonal, dimensi kecerdasan interpersonal, karakteristik kecerdasan interpersonal, faktor yang memengaruhi kecerdasan interpersonal dan pengertian sosiodrama, tujuan pelaksanaan sosiodrama, prosedur pelaksanaan sosiodrama serta cara mengulang permainan sosiodrama.

Sebelum produk buku panduan diserahkan kepada konselor dilakukan revisi sesuai dengan saran dan masukan dari dosen ahli serta calon pengguna produk. Hasil dari perbaikan tersebut diperoleh produk akhir berupa buku panduan. Buku panduan ini diharapkan dapat membantu konselor dalam memberikan layanan bimbingan dan konseling dengan teknik sosiodrama untuk meningkatkan kecerdasan interpersonal siswa Sekolah Menengah Pertama. Buku panduan dicetak berukuran 18,2 cm x 25,7 cm (B5), dijilid buku agar mudah dibawa, tidak mudah rusak dan lebih menarik. Sesuai dengan pendapat Firdayati (2016) bahwa media cetak yang dikembangkan hendaknya bersifat praktis dan dapat dibawa kemanapun. Dengan sampul depan memiliki desain dengan kombinasi kuning, biru dan coklat. Sampul disertai gambar sekelompok siswa yang berada di sekolah, dituliskan identitas peneliti dari universitas, nama lengkap, dan logo Universitas Negeri Malang. Sampul belakang. Pada sampul belakang background panduan memiliki desain dengan warna kuning. Buku panduan ini diberikan warna dominan kuning yang menurut Malkin (1982) warna kuning termasuk dalam 
warna kebahagiaan memiliki sifat toleran, leluasa, santai, penuh harapan dan semangat yang tinggi.

Selain itu, buku panduan sosiodrama untuk meningkatkan kecerdasan interpersonal ini memiliki beberapa kelemahan. Kelemahan tersebut adalah pelaksanaan sosiodrama membutuhkan waktu yang lama karena sekolah memiliki kebijakan hanya satu jam pelajaran untuk BK dan memerlukan ruangan yang cukup luas agar permainan sosiodrama dapat berjalan secara maksimal.

Produk ini juga didukung oleh penelitian Ghassani (2015) bahwa terdapat hubungan antara kecerdasan interpersonal dengan perilaku agresif pada siswa. Penelitian lain yaitu oleh Wulan (2018) mengatakan bahwa layanan bimbingan kelompok dengan teknik permainan dapat meningkatkan kecerdasan interpersonal siswa. Hasil penelitian dari Miftahul (2019) menunjukkan bahwa bermain sosiodrama berpengaruh terhadap kecerdasan interpersonal anak. Hasil penelitian Dewi (2013) mengatakan bahwa teknik sosiodrama dapat meningkatkan kecerdasan interpersonal siswa. Berdasarkan hasil penelitian yang telah dipaparkan bahwa teknik sosiodrama dapat meningkatkan kecerdasan interpersonal siswa.

\section{Simpulan}

Berdasarkan uji coba yang dilakukan diperoleh kesimpulan sebagai berikut: 1) hasil penilaian ahli materi mendapat rata-rata skor 3,6 yang artinya sangat layak 2) hasil penilaian ahli media mendapat rata-rata skor 3,9 yang artinya sangat layak 3) hasil penilaian calon pengguna (konselor) mendapat rata-rata skor 3,9 artinya produk sangat layak. Dengan demikian, produk pengembangan berupa panduan sosiodrama untuk meningkatkan kecerdasan interpersonal siswa layak digunakan oleh konselor yang memenuhi akseptabilitas kegunaan, ketepatan, kemudahan dan kemenarikan.

Dari hasil penelitian yang diperoleh dapat diberikan saran sebagai berikut: 1) Konselor perlu mengatur waktu dengan baik dikarenakan membutuhkan waktu yang cukup panjang dalam memberikan layanan. Selain itu, konselor juga disarankan untuk melaksanakan seluruh skenario sosiodrama secara prosedural, terdiri lima skenario yang tersusun dalam buku panduan 2) Bagi peneliti selanjutnya, diharapkan dapat menindaklanjuti dengan melaksanakan uji kelompok kecil kepada Siswa Menengah Pertama yang tergolong pada skala kecerdasan interpersonal rendah untuk mengetahui keefektifan buku panduan sosiodrama untuk meningkatkan kecerdasan interpersonal.

\section{Daftar Rujukan}

Anggraini, A. P. D., \& Wiyono, B. D. (2020). Pengembangan Buku Panduan Self Regulated Learning Sebagai Media Bimbingan Klasikal untuk Siswa SMPN 3 Taman Sidoarjo. Jurnal BK UNESA, 11(5).

Baloglu, S., \& McCleary, K. W. (1999). A model of destination image formation. Annals of tourism research, 26(4), 868-897.

Cheng, X., Liu, J., \& Dale, C. (2013). Understanding the characteristics of internet short video sharing: A youtubebased measurement study. IEEE transactions on multimedia, 15(5), 1184-1194.

Gall, M. D., Borg, W. R., \& Gall, J. P. (1983). Educational research: An introduction. Longman Publishing.

Gardner, H. E. (2011). Frames of mind: The theory of multiple intelligences. Hachette Uk.

Hurlock, E. B. (2006). Psikologi Perkembangan, Suatu Pendekatan Sepanjang Rentang Kehidupan. Jakarta: Erlangga. 
Jurnal Pembelajaran, Bimbingan, dan Pengelolaan Pendidikan, 1(1), 2021, 21-28

Irani, L. C., Handarini, D. M., \& Fauzan, L. (2018). Pengembangan Panduan Pelatihan Keterampilan Mengelola Emosi sebagai Upaya Preventif Perilaku Bullying Siswa Sekolah Menengah Pertama. Jurnal Kajian Bimbingan dan Konseling, 3(1), 22-32.

Jannah, M. (2019). Pengaruh Bermain Sosiodrama terhadap Kecerdasan Interpersonal Anak Kelompok A di BA Aisyiyah VIII Grogol Tahun Ajaran 2018/2019. Skripsi. Universitas Muhammadiyah Surakarta.

Kumayasari, D. (2013). Penggunaan Teknik Sosiodrama untuk Meningkatkan Kecerdasan Interpersonal Peserta Didik (Penelitian Pra Eksperimen terhadap Siswa Kelas Vii SMP Negeri 1 Lembang). Skripsi. Universitas Pendidikan Indonesia.

Moreno, J. L. (1987). The essential Moreno: Writings on psychodrama, group method, and spontaneity. Springer Publishing Company.

Rasyid, Y. (2021). Pengembangan e-komik sebagai media layanan informasi sopan santun bagi siswa SMP. SKRIPSI Mahasiswa UM.

Kartikosari, R., \& Setyawan, I. (2020). Hubungan Kecerdasan Interpersonal Dengan Intensi Perundungan Pada Siswa Sekolah Menengah Pertama H. Isriati Semarang. Empati, 7(2), 591-596.

Santoso, D. B. (2013). Dasar-dasar Bimbingan dan Konseling.

Savitri, W. T., Yuliansyah, M., \& Fauzi, Z. (2018). Meningkatkan Kecerdasan Interpersonal Siswa Melalui Layanan Bimbingan Kelompok dengan Teknik Permainan Pada Kelas VIII Mts Al-Azhar Kecamatan Alalak Kabupaten Barito Kuala. Jurnal Mahasiswa BK An-Nur: Berbeda, Bermakna, Mulia, 4(1), 26-34.

Primadika, M. A. (2018). Keefektifan Teknik Sosiodrama untuk Meningkatkan Bahasa Reseptif dan Bahasa Ekspresif Siswa. Skripsi. Jurusan Bimbingan dan Konseling.

Romlah, T. (2013). Teori dan Praktek Bimbingan Kelompok. Malang: Universitas Negeri Malang

Tiwasing, W., Sahachaisaeree, N., \& Hapeshi, K. (2014). Design Goals and Attracting Children and Parents' Purchasing Decision. Design Principles and Practices. 7(1), 29-43

Utomo, A. P. Y. (2008). Pengembangan Buku Panduan Menulis Laporan Adengan Pendekatan Kontekstual bagi Siswa SD Kelas VIII SMP. Skripsi: Universitas Negeri Semarang. 